\title{
KERÁMIA DUGATTYÚ GYÁRTÁSA MIKROFOGYASZTÁSÚ VERSENYAUTÓHOZ
}

\section{CERAMIC PISTON MANUFACTURING OF A MICROCONSUMPTION RACE}

\author{
Vaczkó Dániel \\ Kecskeméti Főiskola, GAMF kar, Jármütechnológia tanszék, Magyarország, Kecs- \\ kemét, Izsáki út 10.,Telefon:+36-76-516-387,vaczko.daniel@gamf.kefo.hu
}

\begin{abstract}
In today's prospering world, electric vehicles broaden their horizons. Their presence will be just slightly noticeable in the future because of their high costs and restrained usability. Nowadays most vehicles operate with an internal combustion engine and their development takes a lot of money and effort. The biggest way in developing cars is the increase of efficiency. During our experiment, we did research on delivering a better efficiency, and within that the developments on parts having direct connection with the combustion chamber, namely the piston. After comparing different materials, we chose ceramics as the appropriate piston material.
\end{abstract}

Keywords: piston development, ceramic, $\mathrm{Al}_{2} \mathrm{O}_{3}$, internal combustion engine.

\section{Összefoglalás}

A mai fejlődő világban egyre nagyobb teret hódítanak az elektromos járművek. Ezek korlátozott használhatósága, illetve magas áruk miatt elterjedésük lassan fog bekövetkezni. Manapság is a járművek nagy része belsőégésü motorokkal üzemelnek, fejlesztésükre sok időt és pénzt fordítanak. Az egyik legnagyobb fejlesztési irányvonal a hatásfoknövelés. A kutatásunk során a hatásfok javításával, azon belül az égéssel közvetlen kapcsolatban álló alkatrész fejlesztésével, a dugattyúval foglalkozunk. Különböző anyagok összehasonlítása után, a kerámiát választottuk megfelelő dugattyúanyagnak.

Kulcsszavak: dugattyú fejlesztés, kerámia, $\mathrm{Al}_{2} \mathrm{O}_{3}$, belsöégésü motor.

\section{A fejlesztés szempontjából ideá- lis dugattyú anyag kiválasztása}

A fejlesztés célja, egy olyan dugattyú készítése, amivel a belsőégésű motor hatásfokát növelni lehet. Hatásfokot kétféle módszerrel lehet növelni, a súrlódások csökkentésével, illetve a hőátadás csökkentésével. A kettő közül, a súrlódási viszonyokat is szem elött tartva, elsősorban a hőátadás csökkentését tüztük ki célul. Ezt olyan anyag megválasztásával lehet elérni, amely hővezetési együtthatója a lehető legkisebb. A következő, 1. táblázatban a jelenleg használt, illetve az új dugattyú fejlesztése során használható anyagokat mutatjuk be, a kiemelkedő tulajdonságokkal rendelkező kerámia tulajdonságai az utolsó sorban láthatóak. 
1. táblázat. A lehetséges anyagok

\begin{tabular}{|l|c|c|c|c|}
\hline \multicolumn{1}{|c|}{ Anyag } & $\begin{array}{c}\text { Sürüség, } \\
\mathrm{g} / \mathrm{cm}^{3}\end{array}$ & $\begin{array}{c}\text { Rug. eh., } \\
G P a\end{array}$ & $\begin{array}{c}\text { Hövezetési eh., } \\
W /(\mathrm{m} \mathrm{K})\end{array}$ & $\begin{array}{c}\text { Lin. } \\
\text { hötágulási } \\
\text { eh., } 10^{-6} 1 / K\end{array}$ \\
\hline Öntöttvas & 7,8 & 115 & 60 & 9 \\
\hline $\mathrm{Al}+18 \% \mathrm{Si}$ & 2,7 & 69 & 140 & 17 \\
\hline $\begin{array}{l}\text { Rozsdamentes acél, AISI } \\
302\end{array}$ & 7,86 & 193 & 16,2 & 17,8 \\
\hline Titán Ti-6Al-4V & 4,43 & 114 & 6,7 & 9 \\
\hline A-997 kerámia $\left(\mathrm{Al}_{2} \mathrm{O}_{3}\right)$ & 3,90 & 380 & 24 & $5,4-8,4 \sim 7$ \\
\hline
\end{tabular}

A kerámia az az anyag, ami a jármügyártás terén még eléggé újnak számít. Ritkán, legfeljebb csak kísérleti fázisban használatosak. Az előgyártmány előállítása, majd a készremunkálás körülményes, különleges technológiát igényel, főképp az előző anyagokhoz képest. A fejlesztés céljai tekintetében rendkívül jó tulajdonságokkal rendelkezik. Hővezetése a rozsdamentes acéltól és a titántól csekély mértékben elmarad, de még így is az alumínium ötvözetekhez képest tényezője ötöde. Hőtágulási tényezője nagyon kicsi, így a legkedvezőbb. Súrlódási tényezője viszont rendkívül alacsony. [1]

Az új fejlesztésü dugattyú anyagául a kerámia bizonyul a legmegfelelőbbnek.

\section{2. $\mathrm{Al}_{2} \mathrm{O}_{3}-$ müszaki kerámia}

A kerámia az emberiség életében már több ezer éve jelen van. A kerámia görög szóból ered, jelentése kiégetett. Régen az agyagból és kaolinból kiégetett porcelán tárgyakat nevezték kerámiáknak.

Mára a kerámia szó gyüjtőfogalommá vált. Kerámiának nevezünk minden olyan mesterségesen előállított szervetlen anyagot, amely nemfémesen viselkedik. Ezek az anyagok általában igen nagy villamos ellenállással rendelkeznek, mivel az ezeket lehetővé tevő szabad elektronok a szerkezetéből hiányoznak. [2]
A kerámiák osztályozása több csoportra sorolhatók. A dugattyú fejlesztése során az oxidkerámiák csoportjában található müszaki kerámiák közül az $\mathrm{Al}_{2} \mathrm{O}_{3}$-at fogjuk alkalmazni.

$\mathrm{Az} \mathrm{Al}_{2} \mathrm{O}_{3}$ müszaki kerámiák fontosabb tulajdonságai a fejlesztés szempontjából:

- kis sürüség,

- magas olvadáspont,

- nagy keménység,

- nagy kopásállóság,

- nagy melegszilárdság,

- ridegség, törékenység,

- nehézkes gyárthatóság.

A nyersanyagból előállított porok alkalmazásának két lehetősége van, iszapöntés és sajtolás. Öntésre azok a kerámiák alkalmazhatók, amelyeknek a vízfelvétele széles határok között választható. Sajtolásnál a kerámiapor csak a kötést erősítő anyagokat tartalmaz. Az alakadást követően, a víz kiszárítása után (öntésnél), megfelelő követelményeknek megfelelően kiégetik a terméket. [2]

A dugattyú előgyártmányát sajtolásos módszerrel hozzuk létre, így a továbbiakban ezzel fogunk foglalkozni. A sajtolás többféle módja ismert, ilyen a száraz, nedves, illetve hideg és meleg sajtolás.

Végső tulajdonságait kiégetéssel lehet elérni. A kiégetés nagy hőmérsékleten, álta- 
lában $1300-1600^{\circ} \mathrm{C}$-on történik, amelynek során új fázisok jönnek létre az adalékanyagok hasznosulásával. Hatására csökken a kerámia porozitása, törékenysége, javulnak a mechanikai tulajdonságai. $\mathrm{Al}_{2} \mathrm{O}_{3}$ kerámia esetén az elérhető sürüség a kiégetés hőmérsékletétől is függ. [2]

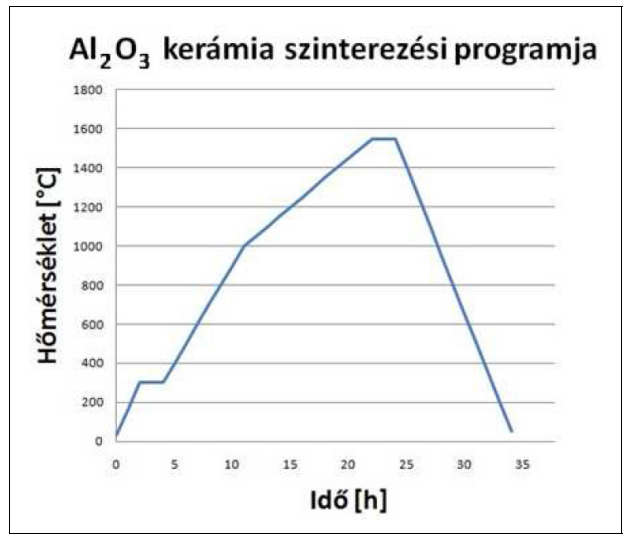

1. ábra. A szinterezés programja [2, 53. oldal]

\section{Gyártás}

Miután kiválasztásra, megismerésre került a kiválasztott anyag, elemeztük a dugattyú igénybevételeit, ezután elkezdtük annak geometria tervezését. A kész geometriával szimulációkat végeztünk, majd a végleges forma segítségével a gyártáshoz szükséges présszerszámot terveztük meg. Az elkészült sajtoló szerszám segítségével a nagypontosságú kerámia alkatrészeket gyártó cég elkészítette a dugattyút.

Az elkészült szerszámmal a gyártónál folytatódott a dugattyú elkészítése. A szerszámot egy speciális gumicsőbe helyeztük bele, majd feltöltöttük a 95\% tisztaságú, 1 $\mu$ m-nél kisebb szemcsenagyságú kerámia porral. A gumicsövet felülről lezártuk, ezután belehelyeztük a présgépbe. A préselést a gépben lévő szobahőmérsékletü víz fogja elvégezni 1000 bar-os (!) nyomással. A présgép ezt a nagy nyomást hidraulikus áttételeken keresztül valósítja meg. A prése- lés közben a porszemcsék között maradt levegő gyors nyomásesés esetén képes szétrepeszteni a préselt darabot, ezért a nyomás leengedése elég kényes müvelet. Az utolsó fázisban a szerszámot ki kell venni az elkészült elögyártmányból. Ez nagy tapasztalatot és kézügyességet igényel.

Az első préselést követően a szerszámot kivéve a préselt előgyártmányból a csapszemböl sajnos le is tört egy kisebb darab. Ezt a problémát szerszám felületén utólag megtalált kisebb hiba okozta. A felületi hibát speciális polírozó szerrel, (disznózsírba kevert gyémántporral) a szerszámon kijavításra került, így a további előgyártmányok sikeresen elkészültek.

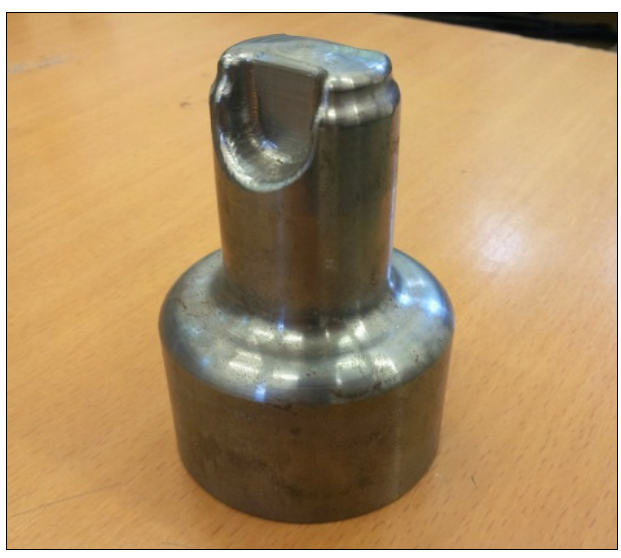

2. ábra. A présszerszám

A következő lépésben esztergálással és marással készült el a külső geometria. Ennél a folyamatnál minden méretet egy megadott értékkel felszorozva kell elkészíteni a munkadarabot a hökezelés közben fellépő zsugorodás miatt. A forgácsolás során a préselt előgyártmány kréta állagú anyagával kell dolgozni, ami a megfogásoknál igen nagy odafigyelést igényel, ugyanis csekély erő alkalmazása esetén az előgyártmány összeroppan. Az előgyártmány kréta állaga ellenére is csak gyémántszerszámokkal munkálható meg. Ez a préselt, kréta állagú anyag rendkívüli módon képes koptatni a 
gyémánt anyagú, illetve a gyémánt bevonatú szerszámokat is. Az esztergálási folyamat a 3. ábrán látható.

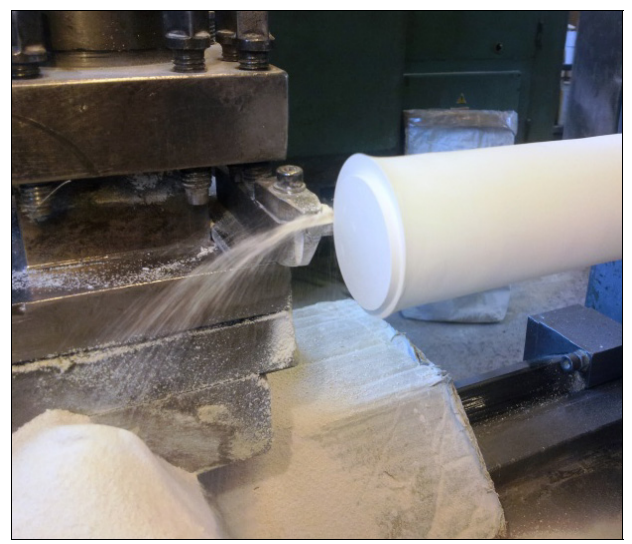

3. ábra. A kerámia elögyártmány esztergálása

A forgácsolás után a darabok kiégetése következett. Ezt 1300-1600 fokon több napon keresztül, fontos és titkos technológiai folyamatok betartásával végeztük. Eközben a szerves kötőanyagok kiégnek és végül a kréta állagból egy igen kemény, most már kerámia anyag lesz. A kiégetés utáni müvelet a köszörülés. A kiégetett kerámia olyan kemény anyaggá válik, amit tisztán csak kötőanyagba ágyazott gyémántszemcsés koronggal lehet köszörülni. A köszörülés során speciális munkadarab készüléket kell igénybe venni a darab ridegségéből adódóan. Ebben a müveletben készült el a müszaki számítások és a szimuláció segítségével meghatározott kúposság, illetve a csapszemfuratok türésezett méretei. Az elkészült alkatrész a 4. ábrán látható.

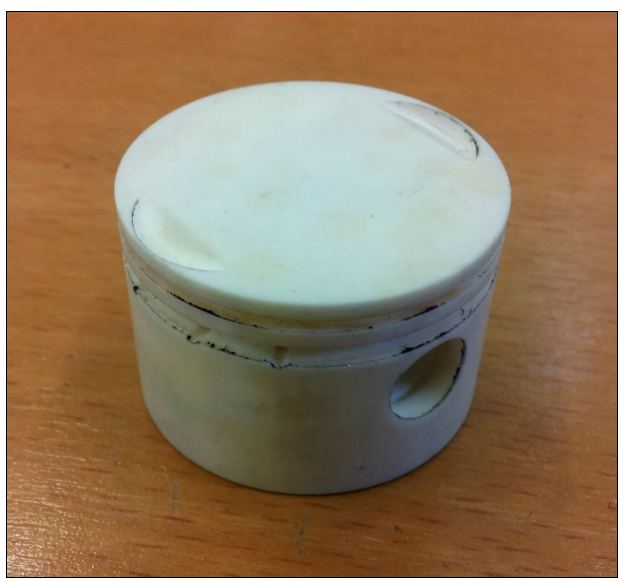

4. ábra. Az elkészült dugattyú

\section{Következtetések}

A gyártás után a szokásos méretellenőrzések kerültek elvégzésre, amely során meggyőződtünk arról, hogy a meghatározott méretek, türések pontosan kerültek legyártásra.

Az utolsó lépésben fékpadi méréseket végeztünk, aminek eredményeiről egy későbbi cikkünkben fogunk beszámolni.

\section{Szakirodalmi hivatkozások}

[1] Vaczkó D.: Mikrofogyasztású versenyautó dugattyú fejlesztése. 2015., OTDK, különdíj

[2] Engyel F.: Alumínium-oxid alapú polimerfeldolgozó szerszámok fejlesztése. 2012. 